\title{
РІЗНОВИДИ ТА СПЕЦИФІКА \\ ВИРАЖЕННЯ ЧАСТКОВИХ ОЦІНОК У ТРЕВЕЛОЗІ ІРЕН РОЗДОБУДЬКО “МАНДРІВКИ БЕЗ СЕНСУ І МОРАЛІ"
}

У статті розглянуто аксіологічно забарвлені мовні одиниці, які широко представлені в сучасних українських тревелогах, зокрема в тревелозі Ірен Роздобудько «Мандрівки без сенсу і моралі». Актуальність дослідження обумовлена тим, що можливість подорожувати світом і пізнавати нову дійсність пов'язана з необхідністю оцінно квалібікувати ії відповідно до власної картини світу й шукати відповідні засоби вираження своїх оиінок. Мета роботи - виявлення основних типів оцінних одиниць. Основним завданням $\epsilon$ ідентифікація мовних ознак їх функціонування в зазначеному творі. У результаті дослідження з'ясовано, що серед часткових оцінок найпоширенішими є смакові, емоційні, естетичні та нормативні оцінки.

Ключові слова: оцінка, тревелог, смак, відчуття, досвід, емоція.

Moshtagh Ye., Ryzhenko M. Varieties and Specificity of the Expression of Partial Evaluations in Iren Rozdobudko's Travelogue "Traveling without Sense and Morality". The article considers axiologically colored language units, which are widely represented in modern Ukrainian travelogues, in particular in the travelogue by Irene Rozdobudko "Travelling without sense and morality".

The relevance of the study is due to the fact that the ability to travel the world and learn a new reality makes it necessary to find the ways to evaluate it in accordance with your own picture of the world and look for appropriate means of expressing your evaluation. The purpose of the work is to reveal the main types of evaluation units used in the book. The main objective is to identify the linguistic features of the functioning of the units.

As a result of the study, it has been found out that among the partial evaluations, gustatory, emotional, aesthetic and normative evaluations are the most common. Gustatory evaluations quite often relate specifically to the sensations from food and drinks. Emotional evaluations are embodied both by direct means and by words in which the emotional content refers to the denotative or connotative components of meaning. They are as dynamic as aesthetic evaluations. Both of these types are characterized by embodiment through adjectives and nouns with appropriate semantics. In aesthetic and normative evaluations, a greater proportion of descriptive means often form antitheses «in Ukraine / abroad», mainly with a negative evaluation of the first component of this opposition. Comfort and convenience while traveling form a utilitarian evaluation, mostly direct. Many supraphrase unities and even sentences in the studied book contain evaluative tools of several types, forming a comprehensive evaluation. 
The conclusion has been made that the linguistic sign of the functioning of the axiologically colored language units is their frequent use in comparative, gradational contexts. In addition to the direct verbalization of evaluation, indirect means are also actively used.

Key words: evaluation, travelogue, taste, sensation, experience, emotion.

\section{Вступ}

Уживання аксіологічно забарвлених мовних одиниць є важливим складником дискурсу тревелогів. Людина, що сприймає нову дійсність, у процесі пізнання оцінно кваліфікує ії згідно з власними поглядами, переконаннями й настановами, а також із картиною світу тих колективів і спільнот, до яких вона належить.

У нашій розвідці розглядаємо аксіологічно забарвлені мовні одиниці, які широко представлені в сучасних українських тревелогах, зокрема в тревелозі Ірен Роздобудько «Мандрівки без сенсу і моралі». Актуальність дослідження пов'язана з тим, що можливість подорожувати світом і пізнавати нову дійсність обумовлює необхідність оцінно кваліфікувати іiі згідно з власною картиною світу й шукати відповідні засоби вираження своїх оцінок. Мета роботи - виявлення основних типів оцінних одиниць. Основним завданням $є$ ідентифікація мовних ознак їх функціонування в зазначеному творі.

Творчість Ірен Роздобудько неодноразово ставала предметом дослідження науковців. Зокрема, концептуалізації мистецтва в сучасному українському жіночому романі на матеріалі творів письменниці присвячена праця О. Башкирової (Башкирова, 2016). Порівняння як мовно-образний засіб творів Ірен Роздобудько досліджує Г. М. Гайдученко (Гайдученко, 2013). Літературознавчу рецепцію творчості письменниці висвітлено у праці Н. В. Галушки (Галушка, 2013). Я. Ю. Голобородько досліджував дотичність текстів і цінностей авторки до української fashion-літератури (Голобородько, 2010), Л. М. Дудченко розглядала досліджуваний нами твір у дискурсі тревелога (Дудченко, 2016). У своїй розвідці спираємось на присвячені оцінності праці Н. Д. Арутюнової (Арутюнова, 1999), О. Л. Бєссонової (Бєссонова, 2005) та В. Д. Шинкарука (Шинкарук, 2011).

\section{Методи дослідження}

Основним методом, використаним у дослідженні, $є$ описовий, застосування якого дало змогу систематизувати характеристики 
досліджуваних одиниць. У процесі добору матеріалу для дослідження залучено метод суцільної вибірки. Контекстний аналіз дав змогу вивчити лінгвальні й екстралінгвальні фактори з урахуванням специфіки ідіостилю Ірен Роздобудько.

\section{Виклад основного матеріалу}

Сенсорно-смакові оцінки надзвичайно широко представлені в жіночих тревелогах, оскільки дійсність у подорожах сприймають через п'ять чуттів і відповідно оцінюють. Хоча до першого різновиду оцінок входять ті, що відповідають усім чуттям, найбільшу частину в нашому матеріалі становлять ті, які базуються власне на смаку. Психологічні підстави цього пояснює в самому тревелозі Ірен Роздобудько: «Людину влаштовано таким чином, що смакові відчуття частіше за будь-які інші (коли, звісно, у Брунеї у вас не закрутився шалений роман з тубільним магнатом) асоціюються з певним місием, у якому ти побував» (Роздобудько, 2011: 9). Предметом смакової оцінки стають найрізноманітніші харчові реаліі: «пиво традиційне, туркуське (смачнюще, до речі, іншого не захочеться!)» (Роздобудько, 2011: 16); «неймовірної смакоти бінський хліб» (Роздобудько, 2011: 22).

Мовною ознакою функціонування зазначених одиниць, як бачимо, $€$ їх часте вживання в порівняльних, градаційних контекстах.

Крім прямої вербалізації оцінок, активно вживаються також непрямі засоби, зокрема психологічні реакції («Забула написати про напій, яким мене можна “купити”, навіть якщзо стану міністром внутрішніх справ. Його називають “тринадиятим иілющим джерелом" Чехії. Натяк зрозуміли? Звісно - “Бехеровка”!» (Роздобудько, 2011: 118).

Смакові відчуття та культура їжі людей відрізняються, тому смакові оцінки можуть бути неоднозначними. Перебуваючи в далеких країнах, авторка порівнює традиційні смаки своєї батьківщини й харчові звички місцевих жителів, засвідчуючи відносність смакових оцінок: «Те, щзо для європейців видається надто гострим, для тубільиів не тільки смачно, але й життєво необхідно! Перець та інші "вогнепальні” приправи дезінбікують продукти, котрі швидко псуються успеку, а також роблять профілактику шлункам» (Роздобудько, 2011: 78). Тут смакова оцінка поєднується з утилітарною. Проте несприйняття певних кулінарних традицій реалізується в негативній оцінці, хоча ця оцінка не має (у досліджуваному тексті) високого ступеня 
категоричності: «Слимаків теж приготовано за особливим родинним рецептом. Їх відварюють, потім особливим чином підсмажують (ие все - разом із панщиром), заправляють купою спецій і трав. Зберігаючи вдячну усмішку, я ледь стримувала нудоту: по-перше, я дуже люблю зворушливих равликів (звісно - живих!), і тому, по-друге, вони мені не смакують. Але з почуття ввічливості змушена була мужньо взятися за спеціальну виделку» (Роздобудько, 2011: 98).

Значно рідше в тексті трапляються інші види сенсорної оцінки. Вони пов'язані з фізіологічними відчуттями комфорту або дискомфорту від клімату: «Гентинг Хайлендз - ие незвичайний гірський район Малайзї, в якому можна відчути справжню прохолоду після втомливого і постійного “парникового ефекту" в нижній частині краӥни» (Роздобудько, 2011: 81). Ряд позитивнооцінних контекстів стосується чистоти повітря: «У Хорватії майже немає важкої промисловості, тому повітря завжди чисте $i$ пахтить, мов носовичок аристократки» (Роздобудько, 2011: 41). Як бачимо, особливістю таких оцінок $є$ вживання тропів: метафоричного епітета й порівняння. Високий ступінь позитивної оцінки експресивно передається через семантику надмірності: «Ароматом петуній тут наскрізь пропахло все, навіть хочеться час від часу понюхати бензину» (Роздобудько, 2011: 41).

Психологічні оцінки, за класифікацією Н. Д. Арутюнової, поділяються на два різновиди: інтелектуальні й емоційні, однак у дослідженому матеріалі було виявлено деякі зразки психологічних оцінок, що мають синтетичну природу й передають риси характеру осіб і народів.

Інтелектуальний різновид психологічних оцінок не є частотним у сучасних українських жіночих тревелогах. Інтелектуальні критерії можуть лежати в основі сприйняття дійсності й інформації в подорожі: «...я нічого не хочу знати до кіния, до останньої виноски в підручнику, котра пояснює те, про що цікавіше будувати власні версї» (Роздобудько, 2011: 104). Однак частіше інтелектуальну оцінку застосовують щодо народу в цілому, а також влади. Оцінку проєктують на історію, давню чи ближчу до сучасності («Подарувати світу легенди - досить мудрий і далекоглядний хід давніх еллінів. У наш час ие можна було б назвати тонким "піаром". Адже ніщо так не приваблює $і$ не збуджує розум людства, як можливість пізнати самого себе» (Роздобудько, 2011: 92). Як бачимо, головними вербалізаторами 
позитивної інтелектуальної оцінки є прикметник і прислівник мудриц̆ / мудро.

Емоційних психологічних оцінок у тревелогах набагато більше. Цілком зрозуміло, що ситуації набуття нового досвіду, контакту культур і людей є емоціогенними. Крім того, сама подорож у сучасному сприйнятті та культурі часто замислюється і сприймається як мандрівка заради нових емоцій.

Емоції вербалізуються і прямими, і непрямими засобами. Як зазначає В. Шинкарук, «мовець може вибрати будь-який спосіб вираження емотивності: номінацію (назва почуття), дескрипцію (опис внутрішнього стану), експресію (вираження почуття за допомогою одиниць усіх рівнів мови)» (Шинкарук, 2011: 32). Прямі називання емоцій $є$ найпростішим засобом фіксації відчуттів і переживань, а також їх заперечення: «Каміння не викликає у мене захвату, особливо якщо ие бутаборія. Принаймні відсотків на 70» (Роздобудько, 2011: 100). Такі емоції супроводжують людину в подорожі весь час, навіть виявляються ще до ії початку: « $€ i$ те, чого боюся, вирушаючи в подорож. Це досить дивний страх: боюся не набратися потрібних $і$ загальноприйнятих вражень. Боюся, що мозок відмовиться сприймати інформацію» (Роздобудько, 2011: 6-7). Типовість почуття для подорожей засвідчують його описи в різних тревелогах.

Назва емоції любов має властивість метонімічно переноситися на об'єкти: «Містечко Умаг на Істринській Рив'єрі - моя найперша любов, враження від якої не стерли інші, респектабельніші чи помпезніші» (Роздобудько, 2011: 40). 3-поміж слів, у яких емоційний компонент міститься в семантиці як додатковий, відзначимо епітети. Прикметник дивовижний є типовим для опису вражень, він трапляється і в тревелозі Ірен Роздобудько: «Інакше неможливо пояснити таку шалену еклектику і дивовижну старовину, котру бачии тут на кожному кроці» (Роздобудько, 2011: 50).

В Ірен Роздобудько епітети з емоційним компонентом несуть неоднозначну емоційну оцінку: «Прокидаєися тут, хоч як ие парадоксально, від тиші. Вона нестерпна і незвична. Навіть трохи моторошна» (Роздобудько, 2011: 40). Наведені епітети характеризують предмет переважно з негативного боку, хоча тиша для людини в подорожі й на відпочинку стандартно асоціюється з позитивними емоціями. 
Універсальними позначеннями пережитих емоцій у тексті $є$ дієслово вразити й іменник враження. При цьому конкретний оцінний знак цих одиниць виявляється тільки в контексті, наприклад: «Паантале - краӥна дітей. Єдина у світі. Враження від неї лишається на все життя» (Роздобудько, 2011: 20). У цій цитаті позитивний оцінний знак міститься в підтексті та випливає з фонових знань. Аналогічно: «Уперше побачивши коло́сів Мемнона, була вражена видовищем... звалища банок з-під «пепсі» довкола їхніх ніг» (Роздобудько, 2011: 6). Вектор оцінки слова вражена прояснюється в контексті: тут вона є негативною, оскільки змінюється сам об’єкт, на який спрямовано емоції.

Промовистою в оцінному аспекті є брак емоцій у ситуаціях, де когнітивний, пізнавальний контекст їх вимагає, тобто в суб'єкта виникають відповідні очікування: “Славнозвісний Сбінкс, перед яким чесно збиралася заплакати сльозами захвату, не викликав жодних емоиій, адже доводилося щохвилинно відбиватись від жвавих торговців-бедуїнів» (Роздобудько, 2011: 6). Найбільш емоційний засіб заплакати сльозами захвату віднесено до минулого часу й описано як ірреальний, а в реальності емоції не виражені, що репрезентовано заперечним реченням з лексикою в прямому значенні. Отже, очікувана позитивна емоційна оцінка трансформується в реальну нульову. I, навпаки, максимально позитивної емоційної оцінки, утіленої в уже згадуваному місткому іменнику враження, набувають певні непередбачувані деталі: «...найбільше враження викликало щось зовсім непоказне - те, про що не варто й говорити, повертаючись із тих краӥв. Скажімо, про ключі, що стирчать ззовні майже всіх дверей на Мальmi» (Роздобудько, 2011: 6).

Слово благодать передає ситуацію високого емоційного піднесення: «Але справжня благодать зійшла на мене у Празі. Відверто кажучи, навіть зараз, пишучи иі рядки, відчуваю внутрішнє тремтіння - добре, що пишу не авторучкою, адже почерк був би досить нерозбірливим...» (Роздобудько, 2011: 109). Назву емоційного стану з високим ступенем позитивної оцінки доповнює та увиразнює опис емоційної реакції.

Значну роль у знайомстві з новими просторами, краєвидами й культурними явищами відіграє естетична оцінка. Цілком зрозуміло, що підхід до побаченого в подорожі з позиції краси - один 
з найтиповіших. Тому слово краса є часто вживаним у тревелогах, причому його вживання не залежить від авторського ідіолекту. «Скрізь є дивовижної краси старовинні храми, костьоли, ратуші, мечеті, пам'ятники, руїни, музеї і загалом - ландиафти, від яких важко відірвати вічко фотооб'єктива» (Роздобудько, 2011: 8).

Іменникову градацію позитивної естетичної оцінки втілюють словосполучення витвір мистецтва та слово шедевр: «Цей иматок тканини сам по собі є витвором мистецтва. Яскраві візерунки поєднують усі кольори веселки. Вся краса жіночого вбрання - в барвистосmi і вільній формі» (Роздобудько, 2011: 83); «різнобарвні котеджики терасами спускаються до синього озера, в якому, мов велетенські кити, причаїлись мальовничі острови. А від чистоти кольорів починають боліти очі» (Роздобудько, 2011: 19). Подорожні враження активізують у свідомості й мові також етичні оцінки. Етика інших лінгвокультурних спільнот стає об'єктом спостереження, осмилення та оцінювання: «У Фінляндії існує правило, яке мені дуже сподобалося: навіть надзвичайно заможна людина не повинна зовні вирізнятися 3-поміж інших викличною розкішию» (Роздобудько, 2011: 20). Фрагмент картини фінського життя містить етичну оцінку, яку внесено в рамку загальної, вираженої дієсловом сподобалося.

Утилітарні оцінки пов'язані зі зручностями, вигодами, перевагами. Найпоширенішими їхніми вербалізаторами є прикметник зручний і прислівник зручно: «Зазвичай туристи набирають носовички, хустинки, барвисті сукні фабричної роботи (дуже зручно ходити в літню спеку по хаті)» (Роздобудько, 2011: 84). Як бачимо, такі мовні засоби використовують здебільшого в описах ситуацій вибору чогось конкретного або в мовленнєвому акті поради.

Необхідно враховувати таку особливість утилітарної оцінки, що iii можна визначити саме як утилітарну лише в контексті. Поза контекстом слова-носії цього різновиду сприймаються як знаки загальної оцінки, але контекстуальне оточення конкретизує їхній зміст. Так само утилітарний зміст у контекстах мають загальнооцінні прикметники високого ступеня оцінки ідеальний, чудовий і носій нормативної оцінки прикметник правильний: «Взагалі Малайзія - ідеальна крайна для шопінгу. Тут усе неймовірно дешеве» (Роздобудько, 2011: 84); «Мушу визнати: готель справді чудовий. Скільки не подорожувала, а таких не бачила. Скрізь чогось бракує. А тут, почавши огляд 
від самого порога, бачу, що враховано навіть праску, не кажучи вже про інші дрібниці, які мають бути у “п'яти зірочках»". Про синхрон телебачення у ванній $і$ два телебони - над ванною і біля унітаза взагалі мовчу» (Роздобудько, 2011: 169).

В основі нормативних оцінок лежать уявлення про правильний туризм, належну організацію подорожі й проведення часу в ній, про доречність або недоречність подій в обставинах подорожі згідно зі світоглядними настановами авторки. Розгляньмо вже процитований вище фрагмент з Ірен Роздобудько, дещо розширивши його контекст: «Я не люблю туризму в чистому вигляді. Не люблю ходити в юрмі. А мари-кидок до чергового музею чи штучних руїн якого-небудь палаиу віддам за посиденьки в таверні і спостереження за вутииями незнайомого міста» (Роздобудько, 2011: 5). Метафоричний іменник марш-кидок належить до групи військової лексики, його семантичні компоненти 'швидкість' і ‘важкість' вказують на недоречність в умовах туристичного відпочинку. Отже, метафора передає нормативну оцінку.

Прикметники галасливиц̆, туристичниц̆, иивілізований і подібні можуть бути використані з різними оцінними знаками в описах місць, але додавання до них прислівників міри й ступеня утворює конструкції зі значенням нормативної оцінки: «Пачевіль, той розважальний район Мальти, де знаходиться Сент-Джуліанс, досить галасливий і надто туристичний. Особливо в иентрі, де до ранку працюють казино та дискотеки» (Роздобудько, 2011: 170).

Мандрівник у подорожі помічає також, що нормативна оцінка в місцевому сприйнятті може відрізнятися від звичної для нього. Тоді зіставлення різних норм показується через зміну суб'єктів у висловленні: «Взагалі, все тут робиться повільно. Місиеві жителі “з колишніх наших" - а таких тут досить багато - можуть навіть зверхньо сказати, що греки, особливо мешканці островів, - ліниві. Але самі острів'яни так не вважають! Щодо иьього у них своя філософія, котру можна сформулювати, як це зробив письменник і білософ Нікос Казандзакіс, звелівщи на своій могилі написати епітабію зі словами: "Я вільний!”» (Роздобудько, 2011: 98, 99). Загалом нормативна й етична оцінки часто тісно переплітаються, коли йдеться про людей.

Аксіологічне сприйняття дійсності в подорожах відбувається 3 різних позицій, тому в контекстах часто поєднуються кілька видів 
оцінок, що утворюють комплексний тип: «Мені дуже сподобалась ізраїльська мода, точніше - ії повна відсутність: одягаються так, як зручно. [...] У иій відсутності моди є своя мода і свій неповторний стиль, котрий дивує лише на початку, а потім видається досить зручним і демократичним» (Роздобудько, 2011: 148). У вислові поєднуються загальна оцінка (сподобалась) і їі часткові різновиди: естетична, утилітарна, нормативна. Усе це формує комплексне враження про фрагмент дійсності: моду й манеру одягатись. «Мальта - надзвичайна. I, незважаючи на те, щь така загадкова і иікава, - вона призначена не для багатьох. Особливо не для тих, хто іде сюди відпочивати, повівщись на туристичні буклети. Відпочивати (маю на увазі - смажитись на сонці і досхочу купатися в морі) тут важко і практично немає де» (Роздобудько, 2011: 186). Негативна утилітарна оцінка врівноважується, ії навіть перебільшує в сприйнятті авторки емоційна.

\section{Висновки}

Отже, ми простежили майже повний спектр часткових оцінок за Н. Д. Арутюновою і переконалися в тому, що вони всі репрезентовані в досліджуваному тревелозі, хоча й з різною частотою. Найбільш уживаними є смакові, емоційні, естетичні та нормативні оцінки.

Серед часткових оцінок поширені смакові, що найчастіше стосуються саме відчуттів від їжі й напоїв. Емоційні оцінки втілюються як прямими засобами, так і словами, у яких емоційний зміст належить до денотативного чи конотативного компонента значення. Вони $€$ динамічними, як і естетичні оцінки. Для обох цих типів характерне втілення через прикметники та іменники з відповідною семантикою. В етичних і нормативних оцінках більшою $є$ питома вага описових засобів, часто формуються антитези «в Україні / за кордоном», здебільшого з негативною оцінкою першого складника цієї опозиції. Комфорт і зручність у подорожах формують утилітарну оцінку, здебільшого пряму, що також впливає на сприйняття дійсності. Численні речення і надфразні єдності в усіх тревелогах містять оцінні засоби кількох типів, формуючи комплексну оцінку.

Зважаючи на те, що твори, які належать до жанру тревелогу, набувають дедалі більшої популярності, маємо підстави вважати перспективним їхнє дослідження в культурологічному й лінгвістичному аспектах. 


\section{ЛІТЕРАТУРА}

1. Арутюнова, Н. Д. (1999). Язык и мир человека. Москва: Языки рус. культуры. 2. Башкирова, О. (2016). Концептуалізація мистецтва в сучасному українському жіночому романі (на матеріалі творів Ірен Роздобудько та Галини Вдовиченко). Літературний процес: методологія, імена, тенденції. Серія «Філол. науки», 8, 3-11. 3. Бєссонова, О. Л. (2005). Вираження оцінки одиницями різних частин мови. Вісн. Запоріз. наи. ун-ту. Філол. науки, 1, 13-17. 4. Гайдученко, Г. (2013). Порівняння як мовно-образний засіб творів Ірен Роздобудько. Наук. вісн. Херсон. держ. ун-ту. Серія «Лінгвістика», 17, 118-120. 5. Галушка, Н. В. (2013). Літературознавча рецепція творчості Ірен Роздобудько. Література в контексті культури, 23 (1), 22-28. 6. Голобородько, Я. (2010). Українська fashion-література : тексти і цінності Ірен Роздобудько. Вісн. Наи. академії наук Украӥни, 1, 44-50. 7. Дудченко, Л. (2016). «Мандрівки без сенсу і моралі» Ірен Роздобудько в дискурсі травелога. Образ, 4, 15-21. 8. Роздобудько, I. (2011). Мандрівки без сенсу і моралі. Київ: Нора-друк. 9. Шинкарук, В. Д. (2011). Особливості реченнєвих структур з емоційно-оцінними значеннями. Studia Linguistica, 5, 29-37.

\section{REFERENCES}

1. Arutyunova, N. D. (1999). Yazyk i mir cheloveka [Human language and world]. Moskva: Yazyki rus. kul'tury [in Russian]. 2. Bashkyrova, O. (2016). Kontseptualizatsiia mystetstva v suchasnomu ukrainskomu zhinochomu romani (na materiali tvoriv Iren Rozdobudko ta Halyny Vdovychenko) [Conceptualization of art in the modern Ukrainian women's novel (based on the works of Irene Rozdobudko and Halyna Vdovychenko)]. Literaturnyi protses: metodolohiia, imena, tendentsii. Filol. nauky - Literary process: methodology, names, trends. Philol. science, 8, 3-11 [in Ukrainian] 3. Biessonova, O. L. (2005). Vyrazhennia otsinky odynytsiamy riznykh chastyn movy [The expression of evaluation units of different parts of speech]. Visn. Zaporiz. nats. un-tu. Filol. nauky Bulletin of the Zaporizhia National university. Philol. science, 1, 13-17 [in Ukrainian]. 4. Haiduchenko, H. (2013). Porivniannia yak movno-obraznyi zasib tvoriv Iren Rozdobudko [Comparison as a linguistic and figurative means of Irene Rozdobudko's works]. Nauk. visn. Kherson. derzh. un-tu. Ser. "Linhvistyka» - Scientific Bulletin of the Kherson State university. Series «Linguistics», 17, 118-120 [in Ukrainian]. 5. Halushka, N. V. (2013). Literaturoznavcha retseptsiia tvorchosti Iren Rozdobudko [Literary reception of Iren Rozdobudko's work]. Literatura $v$ konteksti kultury - Literature in the context of culture, 23 (1), 22-28 [in Ukrainian]. 6. Holoborodko, Ya. (2010). Ukrainska fashion-literatura: teksty i tsinnosti Iren Rozdobudko [Ukrainian fashion literature: texts and values of Irene Rozdobudko]. Visn. Nats. akademii nauk Ukrainy - Bulletin of the National Academy of Sciences of Ukraine, 1, 44-50 [in Ukrainian]. 7. Dudchenko, L. (2016). «Mandrivky bez sensu i morali» Iren Rozdobudko v dyskursi traveloha [«Traveling without sense and morality» by Irene Rozdobudko in the discourse of travellog]. Obraz - Image, 4, 15-21 [in Ukrainian]. 8. Rozdobudko, I. (2011). Mandrivky bez sensu i morali [Traveling without sense and morality]. Kyiv: Nora-druk [in Ukrainian]. 9. Shynkaruk, V. D. (2011). Osoblyvosti rechennievykh struktur $\mathrm{z}$ emotsiino-otsinnymy znachenniamy [The features of sentence structures with emotional and evaluative meanings]. Studia Linguistica, 5, 29-37 [in Ukrainian]. 
Моштаг Євгенія Сергї̈вна - кандидат філологічних наук, доцент кафедри іноземних мов, Харківський національний університет міського господарства імені О. М. Бекетова; вул. Маршала Бажанова, 17, м. Харків, 61000, Україна.

Tel.: +38-050-549-08-39

E-mail: Evgeniamoshtagh@live.com

http://orcid.org/0000-0002-2174-8312

Moshtah Yevheniia Serhiivna - Ph.D. in Philology, Associate Professor at the Department of Foreign languages, O. M. Beketov National University of Urban Economy in Kharkiv; Marshala Bazhanova Str., 17, Kharkiv, 61000, Ukraine.

Риженко Марина Володимирівна - кандидат педагогічних наук, старший викладач кафедри іноземних мов, Харківський національний університет міського господарства імені О. М. Бекетова; вул. Маршала Бажанова, 17, м. Харків, 61000, Україна.

Tel.: +380506613257

E-mail: marina.ryzhenko.89@ukr.net

http://orcid.org/0000-0003-0872-9966

Ryzhenko Maryna Volodymyrivna - Ph.D. in Pedagogy, Senior Lecturer at the Department of Foreign languages, O. M. Beketov National University of Urban Economy in Kharkiv; Marshala Bazhanova Str., 17, Kharkiv, 61000, Ukraine.

Надійшла до редакції 11 вересня 2020 року

\section{CITATION}

ДСТУ 8302:2015: Моштаг Є. С., Риженко М. В. Різновиди та специфіка вираження часткових оцінок у тревелозі Ірен Роздобудько «Мандрівки без сенсу і моралі». Лінгвістичні дослідження: зб. наук. пр. Харк. нац. пед. ун-ту імені Г. С. Сковороди. Харків, 2020. Вип. 53. С. 17-27. DOI: https://doi.org/10.34142/23127546.2020.53.02

APA: Моштаг, Є. С., \& Риженко, М. В. (2020). Різновиди та специфіка вираження часткових оцінок у тревелозі Ірен Роздобудько «Мандрівки без сенсу і моралі». Лінгвістичні дослідження, 53, 17-27. DOI: https://doi.org/10.34142/23127546.2020.53.02 